\title{
Cloning, Expression and in silico Characterization of a Truncated Antiviral Protein Gene from Bougainvillea spectabilis Willd.
}

\author{
Magar Nakul Divakar ${ }^{1}$, S. Rajesh $^{1}$, P. Renukadevi ${ }^{2}$ and B. Rajagopal ${ }^{1,3^{*}}$ \\ ${ }^{1}$ Department of Plant Biotechnology, Centre for Plant Molecular Biology \\ and Biotechnology, Tamil Nadu Agricultural University, Coimbatore- 641003, India \\ ${ }^{2}$ Department of Sericulture, FC\&RI, Mettupalayam- 641301, India \\ ${ }^{3}$ Department of Fruit Science, HC\&RI, Periyakulam-625601, India \\ *Corresponding author
}

\begin{abstract}
A B S T R A C T

\begin{tabular}{|l|}
\hline Key w ord s \\
Bougainvillea \\
spectabilis Willd., \\
Q5 Polymerase, \\
IPTG \\
\hline Article Info \\
\hline Accepted: \\
20 May 2019 \\
Available Online: \\
10 June 2019 \\
\hline
\end{tabular}

Bougainvillea antiviral protein (BAP) is one among a class of the ribosomal inactivating proteins isolated from Bougainvillea spectabilis willd. Truncated version of the BAP gene was cloned and expressed in a prokaryotic vector to abolish its cytotoxicity. RNA was isolated from mature leaves of Bougainvillea and the full length cDNA was amplified by reverse transcription-PCR using template mRNA. This full length cDNA of size 756 bp was amplified using the proofreading polymerase (Q5 polymerase) and end to end gene specific primers for removal of C-terminal, the amplicon was cloned in pJET1.2l vector by blunt end cloning method. Restriction digestion was performed to release the fragment which was further ligated into prokaryotic expression vector pET29a. The recombinant plasmid was transferred into E.coli expression strain BL21 (DE3) and the truncated-BAP gene was expressed by isopropyl $\beta$-D thiogalactopyranoside (IPTG) induction. Transformed colonies expressed recombinant fusion Bougainvillea antiviral protein of molecular weight $\sim 14.6 \mathrm{kDa}$, the size expected for the truncated $B A P$ gene.
\end{abstract}

\section{Introduction}

Many of higher plants extracts reported to possess the antiviral properties shows the presence of certain substances of proteinaceous nature called as Antiviral proteins (AVPs). These AVPs have the property of inhibiting viral protein synthesis by inactivating the ribosomes. As a result, virus replication is inhibited. One such AVP, namely Bougainvillea Antiviral protein
(BAP) with ribosome inactivating property had been isolated from Bougainvillea spectabilis Willd. and characterized in our laboratory, previously. These antiviral proteins are categorized under ribosome inactivating proteins (RIPs). The genes encoding various AVPs have been isolated from many plants (Habuka et al., 1989, Wu et al., 1998, Cho et al., 2000). These genes have been successfully introduced in plants and the transgenic plants expressing AVPs have also 
been reported (Chen et al., 2002, Wallalwar and Balasaraswathi, 2017).

Bougainvillea spectabilisWilld. is a flowering shrub classified under the family Nyctaginaceae. Earlier studies in our lab revealed that the crude extract was able to inhibit several tospoviruses viz., Tomato Spotted Wilt Virus (TSWV), Tobacco Mosaic Virus (TMV) and Cucumber Mosaic Virus (CMV) (Sadasivam et al., 1991). The virus inhibiting factor was determined to be a protein termed, Bougainvillea Antiviral Protein (BAP). The protein was purified and characterized from Bougainvillea spectabilis roots (Balasaraswathi et al., 1998). RIPs/AVPs can offer broad resistance against various virus species and may be a promising strategy to develop resistance against viruses (Wang and Tumer 1999, Zoubenko et al., 2000, Wang and Hudak 2003, Vandenbussche et al., 2004). The present study was aimed to check the effect of C-terminal truncated $B A P$ gene on cytotoxicity towards the expressing host cell.

\section{Materials and Methods}

\section{Plant material}

Fresh, tender leaves samples from Bougainvillea spectabilis (Non host plants) was collected from Botanical Garden, Tamil Nadu Agricultural University, Coimbatore. Various strains of E. coli like DH5 $\alpha$ and BL21 (DE3) were used for cloning and gene expression, respectively.

\section{Isolation and cloning of truncated BAP- cDNA}

Total RNA was extracted from fresh, tender (100 mg) leaves of Bougainvillea spectabilis Willd. using total RNA isolation kit (Sigma Aldrich). cDNA synthesis was carried out by using a commercial kit (Revert Aid First
Strand cDNA Kit, Vilnius, ThermoFermantas -Lithuania). The truncated Bougainvillea antiviral protein gene was isolated by PCR amplification. The gene specific primers were designed for the amplification of full-length bouganin gene based on registered sequences in GenBank (GenBank access number AF445416) using Vector NTI Software. The following PCR cycle was used to amplify the truncated BAP gene: denaturation at $98{ }^{\circ} \mathrm{C}$ for $3 \mathrm{~min}$, followed by 35 cycles of $98^{\circ} \mathrm{C}$ for $30 \mathrm{Sec}$, annealing at $57^{\circ} \mathrm{C}$ for $45 \mathrm{sec}$ and an extension of $72{ }^{\circ} \mathrm{C}$ for $40 \mathrm{sec}$, with a final extension of $72{ }^{\circ} \mathrm{C}$ for $5 \mathrm{~min}$. A $20 \mu \mathrm{L}$ of PCR mixture contained; $1 \mu \mathrm{L}$ of each primer (100 pm(AJ784781.1ol), $10 \mu \mathrm{L}$ of $2 \mathrm{X} \quad \mathrm{Q} 5$ polymerase (High Fidelity Polymerase) master mix (NEB, England), $1 \mu \mathrm{L}$ of cDNA, and $7 \mu \mathrm{L}$ of DNase free water. The amplified DNA was electrophoresed in $1 \%$ agarose gel and the remaining product was purified using a PCR clean-up kit (Biobasic Canada Inc. kit) and directly used for blunt end cloning in pJET1.2 vector having ampicillin resistance as a selectable marker (pJET Cloning Kit, Thermoscientific). E. coli DH5a competent cells were used to transform the clone and recombinant colonies were checked by using colony PCR and restriction digestion (Fig. 1) and the confirmation of positive clone was done by sequencing at Agrigenome Pvt. Ltd., Bengaluru.

Nucleotide sequences were deduced into Amino acid sequences using translate tool in the ExPASy (Expert Protein Analysis System) server. Sequence alignment was carried out using BioEdit software tool(Hall 1999) with amino acid sequences of other antiviral/ribosome inactivating protein producing plants. MEGA X software tool was used to construct the phylogenetic tree by neighbour-joining method (Kumar et al., 2018). 


\section{Construction of vector for inducible in vitro expression of truncated $B A P$ gene}

The eluted product was cloned into the expression vector pET29a between XbaI and XhoI restriction sites located at multiple cloning site of pJET1.2 vector. The digestion reaction mixture $(50 \mu \mathrm{l})$ contained; $12 \mu \mathrm{l}$ of 300 ng pJET1.2 vector containing truncated BAP gene, $2 \mu$ l Cutsmart buffer, $1 \mu$ of each Xbal and $X h o I$ and $34 \mu l$ of nuclease free water and kept for incubation at $37^{\circ} \mathrm{C}$ for 1 hour. The digested product was electrophoresed in $1 \%$ agarose gel. DNA bands were purified using a gel extraction kit (Biobasic Canada Inc. kit) andusing ligation kit, eluted gene was cloned into the pET29a expression vector (Sambrook et al., 1989). E. coli $\mathrm{DH} 5 \alpha$ competent cells were used to transform the clone and recombinant colonies were checked by colony PCR and restriction digestion (Fig. 2) and the confirmation of positive clone was done by sequencing at Agrigenome Pvt. Ltd., Bengaluru.

\section{Expression and purification of recombinant truncated Bougainvillea antiviral protein pET29-BAP-C}

The plasmid from the positive clone was used for transformation of expression strain BL21 (DE3) cells for protein expression through IPTG induction. XbaI and XhoI sites of pET29a vector containing 6X His Tag coding sequence were used to produce the recombinant plasmid. Then, recombinant plasmids harbouring the truncated $B A P$ gene were transformed into competent cells of $E$. coli BL21(DE3) using heat shock method. Luria-Bertani (LB) broth containing kanamycin was used to grow transformed cells at $37^{\circ}$ Covernight. Truncated BAP gene bearing clones were determined by colonyPCR and by restriction digestion. Positive clone identified was grown on LB broth to OD ${ }_{600}$ 0.6. With a consistent shaking for overnight at $37^{\circ} \mathrm{C}$, the bacterial growth was stimulated by adding $10 \mathrm{mM}$ IPTG at different time intervals. The growth media was centrifuged and the bacterial cells were pelleted and resuspended with lysate buffer, suspension was sonicated five times (5s) with gap of $5 \mathrm{~s}$ in ice then kept the mixture for incubation on ice for $35 \mathrm{~min}$. After that protein extract was spin at $10,000 \mathrm{rpm}$ for 15 $\min \left(4^{\circ} \mathrm{C}\right)$. The pellet was resuspended in $10 \% \mathrm{SDS}$ and denatured at $80^{\circ} \mathrm{C}$ for $3 \mathrm{~min}$. and the protein profile was analyzed by SDSPAGE.

\section{Results and Discussion}

\section{Cloning of truncated Bougainvillea antiviral protein gene}

The RT-PCR result revealed that only one specific DNA band of 750 bp in length, was visualized in agarose gel electrophoresis. After cloning in pJET1.2 vector, the gene was sub-cloned in pET29a expression vector. The purified recombinant plasmids were then sequenced bidirectionally to verify the authenticity of the amplicon. The sequencing report showed that truncated BAP gene of size 756 bp shared $84.75 \%$ identity with other isoforms of BAP sequences from Bougainvillea species. The truncated BAP gene was translated into amino acid sequence and has an initiation amino acid methionine (ATG), and terminated by histidine amino acid (CAC).The truncated BAP gene contained a complete open reading frame and had no introns.

\section{In-silico analysis of cDNA encoding truncated $B A P$ gene}

The nucleotide composition of the cDNA as analyzed by the Bio Edit software was found to be: 207 Adenine (27\%), 231 Thymine (32\%), 172 Cytosine (22\%), 146 Guanine (19\%) and the total G + C and A + T content 
was $59 \%$ and $41 \%$ respectively. Thus, based on the nucleotide composition the isolated cDNA was found to be AT rich. A BLAST N search did not show any significant homology of the truncated BAP- cDNA with other known sequences of RIPs/ AVPs from other plants, except $84.75 \%$ and $82.99 \%$ homology with cDNA encoding the AVP of roots (Ap1) and leaves (Bouganin) of Bougainvillea spectabilis, respectively (Altschul et al., 1997). However, Clustal W alignment with different RIPs/AVPs showed a strong homology with the nucleotide sequences of antiviral/ribosome-inactivating protein AAP1 (AY354205.1) and p-1 gene (AJ784781.1) (results not shown).

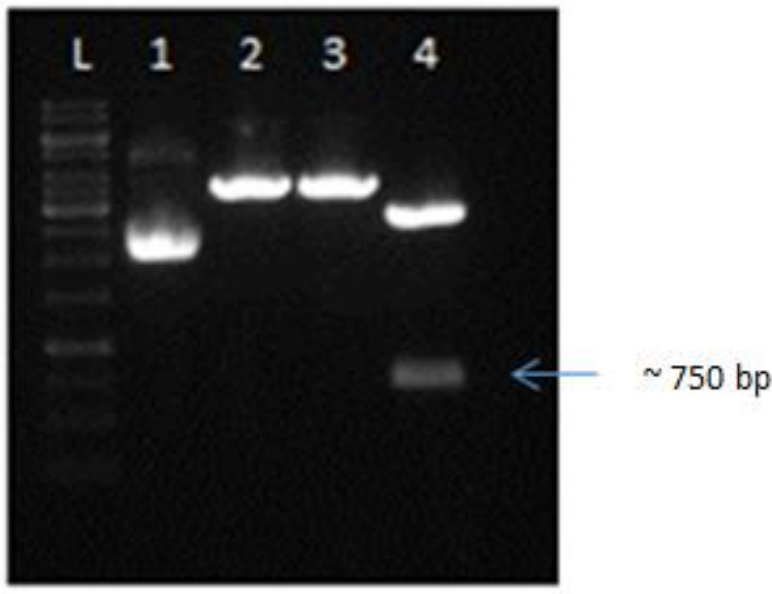

Fig.1 Restriction digestion of pJET- $B A P-C$

(Lane L: 1kb Ladder, Lane 1: Uncut pET29a-BAP-C, Lane 2: Single digestion with $X b a \mathrm{I}$, Lane 3: Single digestion with XhoI, Lane 4: Double digestion with $\mathrm{XbaI}$ and $\mathrm{XhoI}$ )

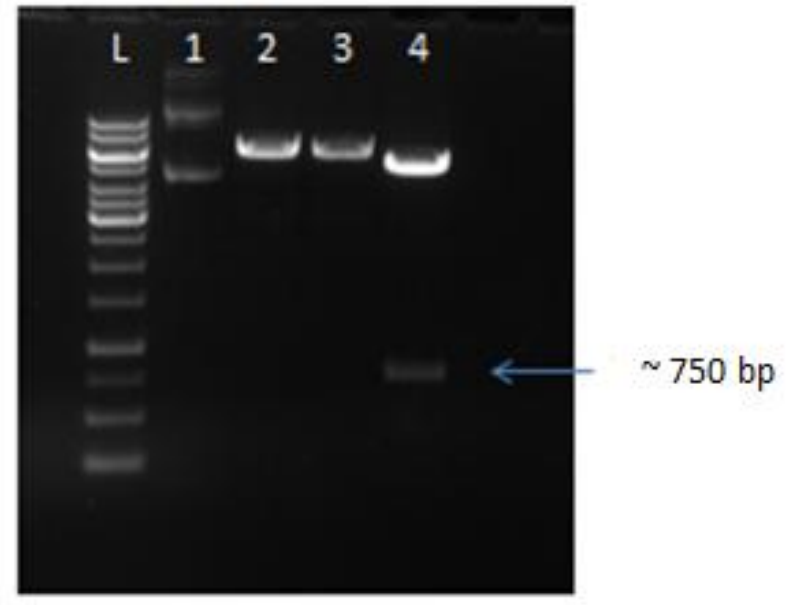

Fig.2 Restriction digestion of pET29a-BAP-C

(Lane L: $1 \mathrm{~kb}$ Ladder, Lane 1: Uncut pET29a-BAP-C, Lane 2: Single digestion with XbaI, Lane 3: Single digestion with XhoI, Lane 4: Double digestion with XbaI and XhoI) 
Int.J.Curr.Microbiol.App.Sci (2019) 8(6): 2828-2836

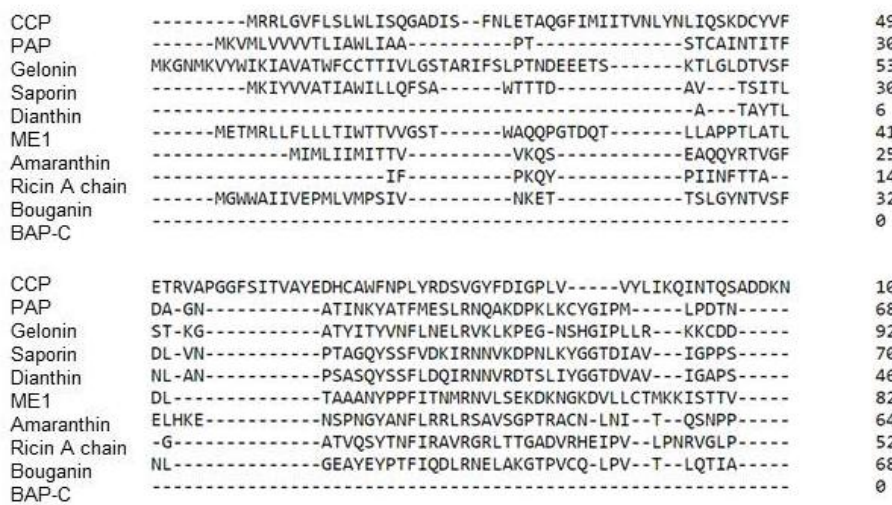

\begin{tabular}{|c|c|c|}
\hline $\mathrm{CCP}$ & FRNRWFPPYYYRADESDTQYVGGN - - MAEYIWGYVDQRYSIFAFLCQPLEEKFLRD- - & 159 \\
\hline PAP & - - STPKYLLVKLQGANLKTITLMLRRNNLYMMGYSDPFNGNKC - - - - RYHIFN - - & 115 \\
\hline Gelonin & $\ldots$ PGKCFVLVALSNDNGQLAEIAIDVTSWYWVGYVRNR - & 135 \\
\hline Saporin & $\cdots$ KDKFLRINFQ-SSRGTVSLGLKRDNLYWVAYLAMDNTN - - - - VNRAYYFKS - - & 116 \\
\hline Dianthin & $\ldots-$ TTDKFLRLNFQ-GPRGTVSLGLRRENLYVWAYLAMDNAN $-\ldots$ & 93 \\
\hline ME1 & $\ldots$...-PSPRYAYVDIKASATQTVTLAIDRTNTYYVLGYRDIFGGTDR $-\ldots \ldots$ AAFFKD - & 129 \\
\hline Amaranthin & - - - IDREYVYIRLQFSDTQWVVLGMAAKDMYIIWGYVDNRPGFGP - -GQPPESNFLM-.. & 115 \\
\hline Ricin A chain & $\ldots$ INQRFILVELSNHAELSVTLALDVTNAYVIVG YRAGNS $\cdots$ & 97 \\
\hline Bouganin & ....-DDKRFVLVDITTTSKKTVKVAIDVTDVYWVGYRDKWDGKDR-.......AVFLD-.. & 114 \\
\hline BAP-C & $\begin{array}{c}\left.*: * \begin{array}{c}* \\
*\end{array}\right] \\
\cdots\end{array}$ & 32 \\
\hline $\mathrm{CCP}$ & .--SRNRPELRESVG-HSMGGNTRPDLWGPTR & 209 \\
\hline PAP & DITSTERTDVENTLCSSSSSRVAMSINYNSLYPTMEKKAEV - - - -NSRNQVQLGFQILSS & 171 \\
\hline Gelonin & 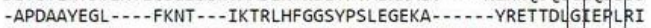 & 181 \\
\hline Saporin & EITSAELTAL - - - FPEATTANQKALEYTEDYQSIEKNAQITQGDKSRKELGLGIDLLLT & 172 \\
\hline Dianthin & QITSAELTAL - ...FPEWVANQKQLEYGEDYQAIEKNAKITTGDQSRKELGLGINLLIT & 149 \\
\hline ME1 & -V-YDDAKDL $\ldots$ FPDAKGKNRIKLSYGSQYTTLG & 173 \\
\hline Amaranthin & DSPPEARQRL - ...FPGS - -N-RRITDYGGNYNSLQQRAQR - ...-NRDNVPLG GTSLPG & 163 \\
\hline Ricin A chain & QEDAEAITHL - ...-FTDV - -QNRYTFAFGGNYDRLEQLAGN - ...--LRENIEL GNGRLEE & 146 \\
\hline Bouganin & 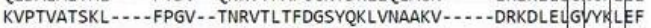 & 163 \\
\hline \multirow[t]{2}{*}{ BAP-C } & EVPSVAIDDL -...-FPGV - -TNREMLTFSGHYQKLQEAAKV -....-NRENLEL GVNKLLGF & 81 \\
\hline & $: \quad] *[*$ & \\
\hline CCP & ALKQL -.....-NTNDGNQDAR-FPLLIDM\$SEAVRFFKHYSAIRGILARPP - NQQNLASI & 260 \\
\hline PAP & DIGKISGVDSF -.-PVKTEAFFLLLAIDMVSEAARFLYYIENQVKTN - -FNRAFYPDDPKVI & 226 \\
\hline Gelonin & GIKKLDENAIDNYK -PTEIASSLLVVIDMVSEAARFFFIENQIRNN - -FQQRIRPANNTI & 238 \\
\hline Saporin & FMEAVNKKARV - - - VKNEARFLLIAIQMTAEYARFRYIQNLVTKN - -FPNKFDSDNKVI & 226 \\
\hline Dianthin & MIDGVNKKVRV-..--VKDEARFLLIAIDMTAEAARFRYIONLVTKN - -FPNKFDSENKVI & 203 \\
\hline ME1 & SITAIYGEAAGTDL-DKNRREFFLLALQMVAEATRFKYYISDKIPTERDYDT - LKVDNHMI & 231 \\
\hline Amaranthin & ALKSVYGKSTSQLNEGNAEARFFLTAIBMVAEAARFKYYIERGISAPPA-...-NFRQNMI & 218 \\
\hline Ricin A chain & AISALYYYSTGGTQ-LPTLARSFIICIBMISEAAHFQYIEGEMRTRIRYNRRSAPDPSVI & 205 \\
\hline \multirow{3}{*}{$\begin{array}{l}\text { Bouganin } \\
\text { BAP-C }\end{array}$} & SIEAIHGKTINGQ--.-EIAKFFLIVIDMVSEAARFFYYIETEVVDRGLYGS-FKPNFKVL & 218 \\
\hline & AIESIYGKALNGK -.... DIARFFLIAIDMVISEAARFKYYIENEVSNNGLYGS -FT -...... & 130 \\
\hline & $:: \quad \quad: \quad: * *: *::^{*}$. & \\
\hline $\mathrm{CCP}$ & ALKDNWARMHFAAIVGKKQLGVN-...... & 283 \\
\hline PAP & NLEEKWGKISEAIHNAKNG -..........ALPI & 276 \\
\hline Gelonin & SLENKWGKLSFQIRTSGAN-G_........-MFSEAVELERANGKKYYVTAVDQVK-PKIALL & 289 \\
\hline Saporin & 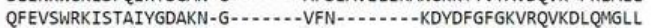 & 270 \\
\hline Dianthin & QFQVSWSKISTAIFGDCKN-G.......VFFN-.......KDYDFGFGKVRQAKDLQMGLL & 247 \\
\hline ME1 & ALENGWDLLSTAIYNAKSS-TTKPTKCELLKTPVSLIWLGQNEWNFNSVEEIA-KVVGLL & 289 \\
\hline Amaranthin & AFQNGWARISTLIHNAEGA- - --TPKCQAFPQPLRIGT & 268 \\
\hline Ricin A chain & TLENSWGRLSTAIQESN-.... QGAFA--SPIQLQRRNGSKFSVYDVSILI-PIIALM & 255 \\
\hline \multirow{2}{*}{$\begin{array}{l}\text { Bouganin } \\
\text { BAP-C }\end{array}$} & NLENNWGDISDAIHKSS -....... PQCTTINPALQLISPSNDPWVNNVVSIS-PDMGIL & 270 \\
\hline & & 130 \\
\hline $\mathrm{CCP}$ & 283 & \\
\hline $\begin{array}{l}\text { CCP } \\
\text { PAP }\end{array}$ & KYVNGTCQTTYQNAMFSQVIISTYYNYMSNLGDLFEGF ..... 314 & \\
\hline Gelonin & KFVDKDPKTSLAAELIIQNY-E -.....SLVGFD -........ 316 & \\
\hline Saporin & MYLGKPKSSNEANSTAYATTVL............................. 292 & \\
\hline $\begin{array}{l}\text { Saporin } \\
\text { Dianthin }\end{array}$ & 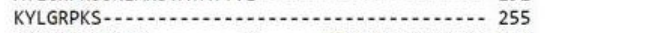 & \\
\hline ME1 & KAKGKKLSTNND & \\
\hline Amaranthin & 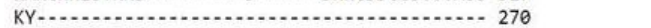 & \\
\hline & VYRCAPPPSSQF & \\
\hline \multirow{2}{*}{$\begin{array}{l}\text { Bouganin } \\
\text { BAP-C }\end{array}$} & KFKSSK--LTQFATMIRSAIVE-.....-. DLDGDELEILEPNIA 305 & \\
\hline & 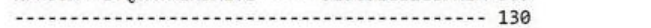 & \\
\hline
\end{tabular}

Fig.3 Amino acid sequence alignment of different RIPs like Saprin (CAA41948.1), Bouganin (AAL35962.1), PAP (CAA66702.1), ME1 (AAN65450.1), Amaranthin (AAD09240.1), Ricin (1OBT), Gelonin (sp|P33186.2), Dianthin (1RL0), CCP (CAH04896.1) compare to deduced amino acid sequence of BAP-C 


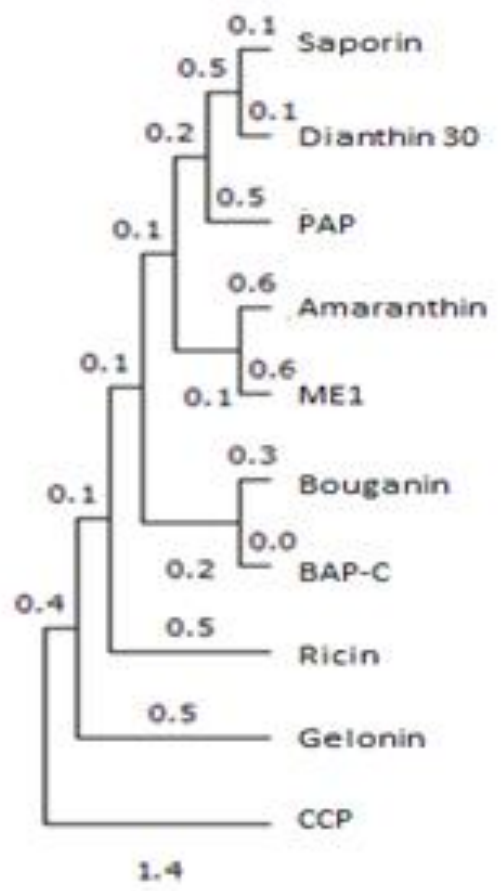

Fig.4 Phylogenetic relationship of BAP-C to different RIPs. The deduced amino acid sequence of BAP-C, Saprin (CAA41948.1), Bouganin (AAL35962.1), PAP (CAA66702.1), ME1 (AAN65450.1), Amaranthin (AAD09240.1), Ricin (1OBT), Gelonin (sp|P33186.2), Dianthin (1RL0), CCP (CAH04896.1)

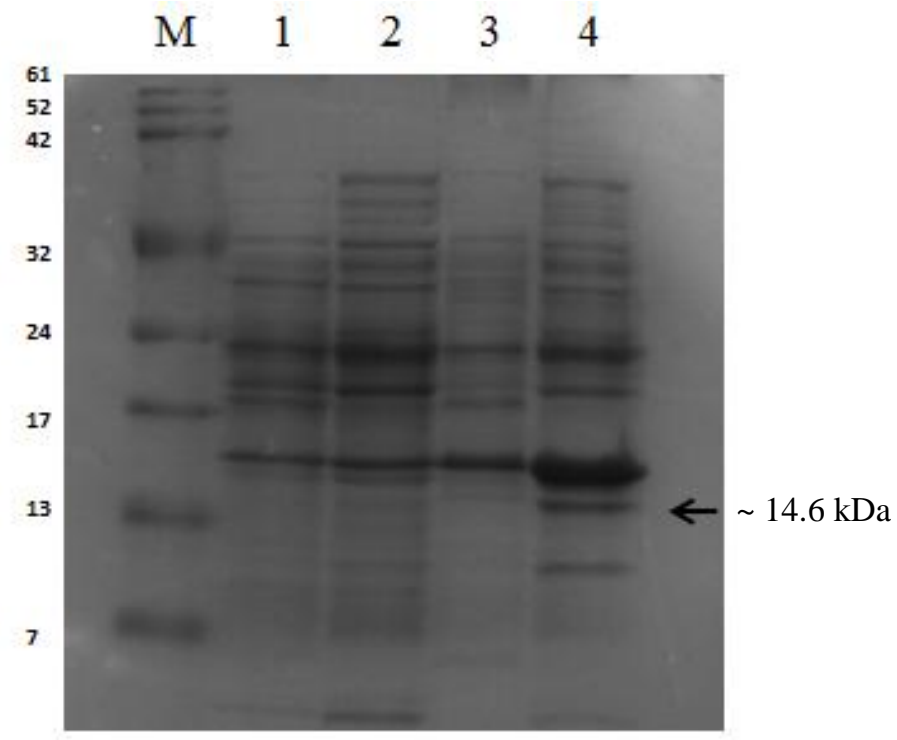

Fig.5 Expression pET-BAP-C in E. coli BL21 (DE3) expression system

The figures shows samples from host cells BL21 uninduced (Lane 1), pET-BAP-C uninduced (Lane 2), BL21 induced (Lane 3) and pET-BAP-C induced $14.6 \mathrm{kDa}$ truncated BAP (Lane 4). Markers are given in lane M. (Molecular masses in $\mathrm{kDa}$ ) 
The truncated BAP-cDNA was translated (www.expasy.com) and deduced amino acids are presented in (Fig. 3). It was found that the ORF of $756 \mathrm{bp}$ encodes 130 amino acid residues. The amino acid composition was checked using the ProtParam tool and shows that the protein is rich in Alanine and Leucine (9.2\%), followed by Valine $(8.5 \%)$ and Asparagine $(7.7 \%)$. The molecular weight of the protein was predicted to be $14.6 \mathrm{kDa}$. The BLASTP ORF-encoded amino acid sequence of BAP showed an identity with different RIPs/AVPs, being maximum with both Bougainvillea antiviral protein and bouganin. Conserved domains were searched with CDD search tool as well as the ClustalW alignment and it was found that the truncated protein showing strong homology with RIP superfamily (cl08249) and amino acid sequences of other RIPs respectively (Fig. 3). The phylogenetic relationship of deduced amino acid sequence of truncated BAP with ten other RIPs/AVPs constructed on the basis of ClustalW alignment is shown in (Fig. 4). The truncated BAP-C and bouganin proteins could be grouped into one cluster with highest bootstrap values. This may be due to the fact that all these AVPs are from two species of Bougainvillea only. The truncated BAP-C cluster was also related to other clusters of AVPs (ME1 and Amaranthin). This may be due to the fact that BAP and ME1 except Amaranthin belong to the same family Nyctaginaceae. While with PAP, Dianthin, Saporin observed a distant relationship of the BAP cluster and there was no relation found with Ricin, Gelonin and CCP.

\section{SDS- PAGE analysis of recombinant truncated-BAP}

The pET29a/BAP-C transformed into E.coli BL21 (DE3) strain, the recombinant protein expressed was induced by IPTG at fixed time intervals. After induction, cells were lysed and the expression profiles of protein compared by SDS-PAGE. Purity of eluted fractions was pertinent and showed a prominent band of $\sim 14.6 \mathrm{kDa}$ to that of fused truncated BAP in case of pET-BAP, whereas there was no distinct band of that size in pET29a control and change in expression of recombinant protein increases after the induction with IPTG (Fig. 5).

Ribosome-inactivating proteins (RIP) have been sharing the property of depurinating the ribosomes irreversibly by catalytic i.e. enzymatic manner (Stirpe 2004). Although diverse studies in ribosomal inactivating proteins were carried out, to know the antiviral mechanism but the actual biochemical function is yet to be understood. Expression levels of RIPs in various plants is enhanced due to infection, other abiotic stresses like salinity, cold and post treatment like jasmonic acids, abscisic acid and mechanical wounding (Reinbothe et al., 1994, Girbes et al., 1996, Rippmann et al., 1997, Song et al., 2000, Iglesias et al., 2008, Tartarini et al., 2010). The gene encoding for BAP was isolated cloned and sequenced (Vipul, 2003). But the E.coli cells grew slowly and putative transformants generated were becoming necrotic even during the callus stage. This may be due to its cytotoxicity to host ribosomes. The cytotoxicity of pokeweed antiviral protein (PAP) was reduced by engineering the corresponding gene by removal of few base pairs from C-terminal (Tumer et al., 1997). Hence, by truncating the BAP-cDNA, the cytotoxicity to the host could be reduced/ removed while the antiviral activity is retained. So to reduce the cytotoxicity, the gene truncated at the C-terminal was cloned and normal growth of transgenic calli and transformants was observed. For the cloning and expression of recombinant proteins produced by the target gene in E. coli, pET expression system is the most powerful system. In this system, strong bacteriophage 
T7 signals with transcriptional/translational control drives the target genes cloned; by providing T7 RNA polymerase source in the host cell which induces gene expression so that when there is full induction and conversion of almost all of the cell's resources to target gene expression and within a few hours after induction the desired product accounts for about more than $50 \%$ of the total cell protein (Novagen 2002). A 756 bp of truncated $B A P-C$ gene cloned and expressed in pET29a/ BL21 (DE3) system and has shown truncated BAP of mass 14.6 $\mathrm{kDa}$.

Truncated BAP gene was overexpressed in tomato plants to produce resistance against tospoviruses (Wallalwar and Balasaraswathi 2017). Antioxidant activity CCP and BAP was reported (Gholizadeh et al., 2004, Bhatia et al., 2004). The results can be utilized for expressing the truncated $B A P$ in transgenic plants for evolving virus resistance. The overexpression of these antiviral/RIP genes in transgenic studies could be interesting and will be effective in better understanding of the physiological functions of different stressrelated defense genes.

\section{Acknowledgements}

Magar Nakul Divakar is grateful to the Department of Biotechnology, Govt. of India, New Delhi for grant of Research Fellowship. We are grateful to the crews of NCBI, EBI, for making computational biology data/tools publicly available.

\section{References}

Altschul, Stephen F, Thomas L Madden, Alejandro A Schäffer, Jinghui Zhang, Zheng Zhang, Webb Miller, and David J Lipman. 1997. "Gapped BLAST and PSIBLAST: a new generation of protein database search programs." Nucleic acids research 25 (17):3389-3402.
Balasaraswathi, R, S Sadasivam, M Ward, and JM Walker. 1998. "An antiviral protein from Bougainvillea spectabilis roots; purification and characterisation." Phytochemistry 47 (8):1561-1565.

Bhatia, Shikha, HC Kapoor, and ML Lodha. 2004. "Modification of antioxidant status of host cell in response to Bougainvillea antiviral proteins." Journal of plant biochemistry and biotechnology 13 (2):113-118.

Cho, Hwa-Jin, Sang-Jik Lee, Shinje Kim, and Byung-Dong Kim. 2000. "Isolation and characterization of cDNAs encoding ribosome inactivating protein from Dianthus sinensis L." Molecules and cells 10 (2):135-141.

Gholizadeh, Ashraf, Manoj Kumar, A Balasubrahmanyam, Sushil Sharma, Sneh Narwal, ML Lodha, and HC Kapoor. 2004. "Antioxidant activity of antiviral proteins from Celosia cristata." Journal of plant biochemistry and biotechnology 13 (1):1318.

Girbes, Tomas, Carlos de Torre, Rosario Iglesias, Jose Miguel Ferreras, and Enrique Méndez. 1996. "RIP for viruses." Nature 379 (6568):777.

Habuka, N, Y Murakami, Masana Noma, T Kudo, and K Horikoshi. 1989. "Amino acid sequence of Mirabilis antiviral protein, total synthesis of its gene and expression in Escherichia coli." Journal of Biological Chemistry 264 (12):6629-6637.

Hall, Tom A. 1999. "BioEdit: a user-friendly biological sequence alignment editor and analysis program for Windows 95/98/NT." Nucleic acids symposium series.

Iglesias, Rosario, Yolanda Pérez, Lucía Citores, José M Ferreras, Enrique Méndez, and Tomás Girbés. 2008. "Elicitor-dependent expression of the ribosome-inactivating protein beet in is developmentally regulated." Journal of experimental botany 59 (6): 1215-1223.

Novagen, I. 2002. pET system manual. Novagen Madison, WI.

Reinbothe, Steffen, Christiane Reinbothe, Jorg Lehmann, Walter Becker, Klaus Apel, and Benno Parthier. 1994. "JIP60, a methyl jasmonate-induced ribosome-inactivating protein involved in plant stress reactions." 
Proceedings of the National Academy of Sciences 91 (15):7012-7016.

Rippmann, Joerg F, Christine B Michalowski, Donald E Nelson, and Hans J Bohnert. 1997. "Induction of a ribosome-inactivating protein upon environmental stress." Plant molecular biology 35 (6):701-709.

Sadasivam, S, S Rajamaheswari, and R Jeyarajan. 1991. "Inhibition of certain plant viruses by plant extracts." Journal of Ecobiology 3 (1):53-57.

Sambrook, Joseph, Edward F Fritsch, and Tom Maniatis. 1989. Molecular cloning: a laboratory manual: Cold spring harbor laboratory press.

Song, Sang-Kee, Yeonhee Choi, Young Ho Moon, Sang-Gu Kim, Yang Do Choi, and Jong Seob Lee. 2000. "Systemic induction of a Phytolacca insularis antiviral protein gene by mechanical wounding, jasmonic acid, and abscisic acid." Plant molecular biology 43 (4):439-450.

Stirpe, Fiorenzo. 2004. "Ribosome-inactivating proteins." Toxicon 44 (4):371-383.

Tartarini, Andrea, Eugenia Pittaluga, Giordana Marcozzi, Giulio Testone, Renato Alberto Rodrigues- Pousada, Donato Giannino, and Laura Spanò. 2010. "Differential expression of saporin genes upon wounding, ABA treatment and leaf development." Physiologia plantarum 140 (2):141-152.

Tumer, Nilgun E, Duk-Ju Hwang, and Maureen Bonness. 1997. "C-terminal deletion mutant of pokeweed antiviral protein inhibits viral infection but does not depurinate host ribosomes." Proceedings of the National Academy of Sciences 94 (8):3866-3871.

Vandenbussche, Frank, Stijn Desmyter,
Marialibera Ciani, Paul Proost, Willy J Peumans, and Els JM Van Damme. 2004. "Analysis of the in planta antiviral activity of elderberry ribosome- inactivating proteins." The FEBS Journal 271 (8):15081515.

Vipul. 2003. "Cloning and characterization of cDNA encoding an antiviral protein from Bougainvillea spectabilis Willd." M.Sc., Department of Plant Biotechnology, Tamil Nadu Agricultural University.

Wallalwar, Mayur R, and R Balasaraswathi. 2017. "Cloning and Transformation of Engineered Bougainvillea Antiviral Gene in Tomato Plant." Int. J. Curr. Microbiol. App. Sci 6 (6):1714-1722.

Wang, Melan, and Katalin A Hudak. 2003. "Applications of plant antiviral proteins." In Genetic engineering, 143-161. Springer.

Wang, Pinger, and Nilgun E Tumer. 1999. "Pokeweed antiviral protein cleaves doublestranded supercoiled DNA using the same active site required to depurinate rRNA." Nucleic acids research 27 (8):1900-1905.

$\mathrm{Wu}$, Tsann- Huei, Lu- Ping Chow, and Jung- Yaw Lin. 1998. "Sechiumin, a ribosome- inactivating protein from the edible gourd, Sechium edule Swartz: Purification, characterization, molecular cloning and expression." European journal of biochemistry 255 (2):400-408.

Zoubenko, Oleg, Katalina Hudak, and Nilgun E Tumer. 2000. "A non-toxic pokeweed antiviral protein mutant inhibits pathogen infection via a novel salicylic acidindependent pathway." Plant molecular biology 44 (2):219-229.

\section{How to cite this article:}

Magar Nakul Divakar, S. Rajesh, P. Renukadevi and Rajagopal, B. 2019. Cloning, Expression and in silico Characterization of a Truncated Antiviral Protein Gene from Bougainvillea spectabilis Willd.. Int.J.Curr.Microbiol.App.Sci. 8(06): 2828-2836.

doi: https://doi.org/10.20546/ijcmas.2019.806.341 